\title{
PELATIHAN DAN PENDAMPINGAN PENGOLAHAN KOMODITAS KELAPA
}

\section{COCONUT COMMODITIES TRAINING AND ASSOCIATION PROCESSES}

\author{
Mulono Apriyanto \\ Fakultas Pertanian Prodi Teknologi Pangan \\ Universitas Islam Indragiri \\ Jl. Propinsi Parit 1 Tembilahan- Indragiri Hilir Riau \\ mulonoapriyanto71@gmail.com
}

\begin{abstract}
ABSTRAK
Permasalahan yang dihadapi mitra pertama yaitu Kelompok Tani Sinar Bahagia adalah tidak mengetahui diversifikasi komoditi kelapa, pendapatan petani kelapa yang rendah, tidak mengetahui cara pemasaran produk dan memiliki sikap yang pasrah terhadap keadaan. Sedangkan permasalahan yang dihadapi mitra kedua yaitu Kelompok PKK Desa Pasir Mas adalah kurangnya jenis kegiatan produktif dan tidak mengetahui cara pemasaran produk. Berangkat dari permasalahan tersebut kedua mitra sepakat akan mengolah bagian kelapa yang selama ini dibuang begitu saja (air kelapa) padahal dapat diproduksi menjadi produk turunan yang bernilai ekonomi (produk nata de coco). Tujuan kegiatan pendampingan dan pelatihan kelapa adalah bentuk kegiatan pengabdian masyarakat dan bermitra dengan Desa Pasir Mas guna diversifikasi Komoditi Kelapa. Melalui mitra yakni Kelompok Tani Sinar Bahagia dan Kelompok PKK Desa Pasir Mas adalah meningkatkan pendapatan mitra dengan cara memproduksi dan memasarkan produk dari diversifikasi komoditi kelapa (nata de coco). Metode pelaksanaan yang dilakukan dalam kegiatan ini adalah : (1) memberikan pelatihan pembuatan nata de coco, (2) pelatihan dan pendampingan pemasaran. Hasil dari kegiatan adalah meningkatnya pengetahuan dan ketrampilan mitra, terciptanya produk nata Pasir Mas, publikasi pada media massa, serta adanya email, akun instagram dan sipindo untuk memasarkan produk secara online.
\end{abstract}

Kata kunci: Diversifikasi; Kelapa; Nata; Pelatihan; Pendampingan

\begin{abstract}
The problem faced by the first partner is the Sinar Bahagia Farmers Group does not know the diversification of coconut commodities, low income of coconut farmers, not knowing how to market the product and having a surrendering attitude towards the situation. While the problems faced by the second partner, namely the PKK Village Pasir Mas, are a lack of types of productive activities and do not know how to market products. Based on the problem, the two partners agreed to process the coconut part which had been thrown away (coconut water) even though it could be produced into derivative products of economic value (nata de coco products). The purpose of coconut assistance and training activities is a form of community service activities and partnering with Pasir Mas Village to diversify Coconut Commodities. Through partners, namely Sinar Bahagia Farmers Group and PKK Pasir Mas Village is increasing partner income by producing and marketing products from coconut commodity diversification (nata de coco). The implementation methods carried out in this activity are: (1) providing training in making nata de coco, (2) training and marketing assistance. The results of the events are increased knowledge and skills of partners, the creation of Pasir Mas nata products, publications in the mass media, and the existence of e-mail, Instagram accounts and IDs to market products online.
\end{abstract}

Keywords: Diversification; Coconut; Nata; Workshop; Supervision 
Mulono Apriyanto

Pelatihan Dan Pendampingan Pengolahan Komoditas Kelapa

Submitted : 13 Desember 2018

Revision : 30 Maret 2019

Accepted: 20 Juni 2019

\section{PENDAHULUAN}

Air kelapa (Cocos nucifera) seringkali terbuang dan menimbulkan masalah akibat aromanya yang kuat setelah beberapa waktu dibuang ke lingkungan. Pengolahan limbah air kelapa dapat dilakukan secara sederhana melalui pembuatan nata de coco. Pembuatan produk ini dapat membantu mengatasi timbulnya pencemaran limbah air kelapa (Djajanegara, 2010, Apriyanto, et al, 2007 ).

Pembendayaan dapat menjadi salah satu pendekatan pembangunan dalam proses penguatan ekonomi dan sosial untuk meningkatkan kesejahteraan hidup masyarakat, utamanya di pedesaan (Daulay, 2006). Pemberdayaan ekonomi masyarakat pedesaan dalam bentuk pengabdiam msyarakat serta pembinaan dititk beratkan pada kelompok tani dan PKK. PKK atau pembinaan kesejahteraan keluarga merupakan program yang diberdayakan oleh pemerintah dalam bentuk organisasi kemasyarakatan sudah sejak lama, tak terhitung jumlah dan hasil serapan yang ada di wilayah indonesia secara nasional (Collado, 1986). Permasalahan limbah air kelapa yang cukup tinggi dan kurangnya keterampilan dalam hal pengolahan limbah tersebut menjadikan pemberdayaan perempuan dalam pengolahan nata de coco penting dilakukan. Nata merupakan hasil fermentasi Acetobacter xylinum dengan substrat yang mengandung gula (Hamad, et al., 2014). Jika substrat yang digunakan adalah air kelapa, maka umumnya dikenal sebagai nata de coco. Produk ini banyak dikenal masyarakat dan memiliki nilai ekonomi yang cukup tinggi. Adapun pelatihan pembuatan nata de coco yang pernah dilakukan kepada ibu ibu PKKmasih menghasilkan nata decoco yang berkualitas rendah karena aromanya masih berbau. Oleh karenanya ibu-ibu
PKK mengharapkan adanya pelatihan dan pendampingan kembali agar dapat menghasilkan nata de coco yang berkualitas sehingga layak untuk dipasarkan. Disamping itu, Kelompok PKK Desa Pasir Mas suatu waktu pernah memproduksi nata de coco tetapi hanya dijadikan sebagai konsumsi sendiri/keluarga dan kelompok PKK saja dikarenakan ketidak mampuannya melakukan pemasaran.

\section{METODE}

Lokasi pelatihan dipusatkan di Aula Bidang Ketahanan Pangan, Dinas Ketahanan Pangan Pemerintah Kabupaten Indragiri. Peserta diberikan pemahaman terlebih dahulu melalui penyampaian materi pentingnya pengolahan limbah air kelapa untuk mengurangi pencemaran lingkungan dan peningkatan nilai ekonomi limbah tersebut. Praktik pembuatan nata de coco dilakukan secara langsung setelah materi lengkap tersampaikan. Praktik dimulai dengan proses pembuatan starter dari buah nanas.

Starter merupakan salah satu bahan penting dalam pembuatan nata. Peserta diajarkan membuat starter agar nantinya dapat mengembangkan sendiri bibit untuk pembuatan nata tanpa harus membeli dari industri. Buah nanas merupakan substrat yang dapat digunakan sebagai media tumbuh Acetobacter xylinum yang berperan penting dalam pembuatan nata (Maharani, et al., 2016). Pembuatan nata de coco tidak memerlukan peralatan khusus (Oedjijono, 1983). Alatalat rumah tangga yang umum tersedia di rumah dapat digunakan sehingga ibu-ibu pun tidak akan kesulitan dalam penyediaan alat untuk pembuatan nata.

Metode yang diterapkan dalam pemberdayaan masyarakat pada kegiatan pengabdian masyarakat ini adalah sebagai berikut: (1) Penyuluhan untuk membangun persepsi dan pemahaman masyarakat 
Mulono Apriyanto

Pelatihan Dan Pendampingan Pengolahan Komoditas Kelapa

khususnya PKK di desa Pasir Mas mengenai inovasi atau program pembuatan VCO yang diterapkan, (2) Pelatihan mengenai terapan ipeks yang diaplikasi bagi masyarakat, dan (3) Pendampingan yaitu pertemuan secara berkala dan berkelanjutan antara pendamping dengan masyarakat sasaran hingga ipteks pembuatan VCO yang diaplikasikan dapat dilaksanakan secara tepat oleh angota PKK dan kelomppok tani.

Adapun proses pembuatan nata de coco diuraikan sebagai berikut :

\section{Bahan dan Alat}

Pembuatan nata de coco membutuhkan air kelapa, nanas, gula pasir, cuka makan, ekstrak tauge, starter nata, panci, nampan, pengaduk, sendok makan, kompor, koran, karet, saringan plastik, dan toples kaca.

\section{Pembuatan Starter}

Satu buah nanas dikupas, dibersihkan dan kemudian diblender. Bubur nanas kemudian diperas dan diambil ampasnya. Gula pasir ditambahkan dengan perbandingan nanas:gula:air $=2: 1: 1$ (misal nanas $1 \mathrm{~kg}$, gula $1 / 2 \mathrm{~kg}$, dan air $1 / 2$ liter). Campuran tersebut kemudian dimasukkan ke dalam toples kaca dan difermentasi selama 7 hari di suhu ruang hingga terbentuk 2 lapisan. Starter yang terbentuk berupa cairan yang terdapat di lapisan bagian bawah (Maharani et al., 2016).

\section{Proses Pembuatan Nata de Coco}

Air kelapa mentah disaring dan dimasukkan ke dalam panci stainless ukuran sedang kemudian dimasak sampai mendidih $100^{\circ} \mathrm{C}$. Kompor dimatikan sejenak untuk penambahan 50 gram gula pasir, cuka makan, dan 2 sdm ekstrak tauge. Campuran tersebut dipanaskan kembali hingga mendidih, kemudian dimasukkan ke dalam nampan plastik yang bersih atau steril. Nampan-nampan plastik tersebut ditutup dengan kertas Koran steril yang telah disetrika sebelumnya. Penutup Koran dikencangkan dengan karet atau tali kemudian disusun secara rapi dan ditunggu dingin untuk ditambah starter nata de coco. Nampan hasil pembibitan tidak boleh terganggu atau tergoyang. Inkubasi dilakukan selama 7 hari. Pemanenan Nata yang terbentuk dalam nampan diambil dan dibuang bagian yang rusak (jika ada). Nata tersebut kemudian dibersihkan dan direndam dalam air bersih selama 1 hari. Pada hari kedua, air rendaman diganti dan direndam kembali selama 1 hari. Pada hari ketiga, nata dicuci bersih dan dipotong bentuk kubus kemudian direbus hingga mendidih dan air rebusan pertama dibuang. Nata yang telah dibuang airnya tadi kemudian direbus lagi dan ditambahkan dengan satu sendok makan asam sitrat.

\section{HASIL DAN PEMBAHASAN}

Praktik pembuatan nata de coco bagi PKK dan Kelompok Tani desa Pasir Mas di Kabupaten Indragiri Hilir dapat meningkatkan keterampilan peserta yang sebelumnya tidak bekerja di luar rumah. Dengan adanya keterampilan baru yang dipelajari, diharapkan para ibu dapat memproduksi nata dalam skala rumah tangga sehingga mampu membantu perekonomian rumah tangganya. Potensi nata de coco untuk dikembangkan dalam industri rumah tangga didukung oleh manfaatnya yang banyak diminati oleh masyarakat. Tingkat konsumsi nata cukup tinggi terkait dengan rendahnya kalori yang terkandung dalam nata sehingga baik dikonsumsi oleh orang yang sedang menjalani diet. Nata juga kaya akan serat yang dapat melancarkan pencernaan makanan (Kristianingrum, 2004). Air kelapa yang digunakan dalam pembuatan nata disaring terlebih dahulu untuk menghilangkan kotoran yang terlarut. Pemasakan hingga mendidih agar bakteri kontaminan tidak mengganggu proses berikutnya sehingga hanya A. xylinum yang tumbuh dalam media pembuatan nata tersebut.

Pemanenan dilakukan setelah lapisan selulosa terbentuk dalam media pertumbuhan. Kualitas nata yang dihasilkan tergantung pada jumlah 
populasi A. xylinum pada starter yang digunakan (Hamad et al., 2014). Peserta pelatihan menunjukkan antusiasme tinggi selama proses praktik pembuatan nata. Antusiasme tersebut ditunjukkan dengan respon peserta yang sangat baik dalam menerima materi mengenai nata de coco serta kemauan peserta untuk terlibat dalam setiap tahap proses pembuatan nata. Antusiasme peserta tersebut diharapkan dapat meningkatkan pemberdayaan ibu-ibu dalam bidang pengolahan pangan sehingga air kelapa yang sebelumnya hanya dibuang, dapat dimanfaatkan dan dikembangkan menjadi olahan pangan yang memiliki nilai ekonomi tinggi. Hal ini ditunjukan juga dalam evaluasi diawal dan diakhir pelatihan hasil evaluasi tersaji pada tabel 1.

Tabel 1. Hasil evaluasi

\begin{tabular}{|c|c|c|c|c|}
\hline No & $\begin{array}{c}\text { Instruksional } \\
\text { khusus }\end{array}$ & $\begin{array}{l}\text { Butir } \\
\text { Soal }\end{array}$ & $\begin{array}{c}\text { Jumlah } \\
\text { soal }\end{array}$ & Prosentase \\
\hline 1 & $\begin{array}{l}\text { Mengetahui } \\
\text { pemahaman } \\
\text { peserta } \\
\text { tentang nata } \\
\text { de coco }\end{array}$ & 1,2 & 2 & 20 \\
\hline 2 & $\begin{array}{l}\text { Meningkatkan } \\
\text { pengetahuan } \\
\text { peserta } \\
\text { mengenai } \\
\text { manfaatnata } \\
\text { de coco }\end{array}$ & 3,4 & 2 & 20 \\
\hline 3 & $\begin{array}{l}\text { Meningkatkan } \\
\text { pengetahuan } \\
\text { peserta } \\
\text { tentang bahan } \\
\text { baku untuk } \\
\text { pembuatan } \\
\text { nata de coco }\end{array}$ & 5,6 & 2 & 20 \\
\hline 4 & $\begin{array}{l}\text { Meningkatkan } \\
\text { pengetahuan } \\
\text { peserta } \\
\text { tentang bahan } \\
\text { aditif untuk } \\
\text { pembuatan } \\
\text { nata de coco }\end{array}$ & 7,8 & 2 & 20 \\
\hline 5. & $\begin{array}{l}\text { Meningkatkan } \\
\text { pengetahuan } \\
\text { peserta } \\
\text { tentang cara } \\
\text { pembuatan } \\
\text { nata de coco }\end{array}$ & 9,10 & 2 & 20 \\
\hline
\end{tabular}

\section{SIMPULAN}

Pelatihan dan pendampingan ini dapat meningkatkan pengetahuan dan ketrampilan mitra dalam mengolah air kelapa menjadi produk nata de coco, serta meningkatkan pengetahuan dalam memasarkan barang tidak hanya melalui cara tradisonal tetapi juga dapat dilakukan dengan memanfaatkan media sosial yang ada.

\section{DAFTAR PUSTAKA}

Collado, L. S. (1986). Processing And Problem Of The Industry In The Philipines. Traditional Food And Their Processing In Asia, November, Yokyo

Daulay, H. (2006). Pemberdayaan perempuan (Studi kasus pedagang jamu di Gedung Johor Medan). Jurnal Harmoni Sosial 1(1): 7-14.

Djajanegara, I. (2010). Pemanfaatan limbah buah pisang dan air kelapa sebagai bahan media kultur jaringan anggrek bulan (Phalaenopsis amabilis) tipe 229. Jurnal Teknologi Lingkungan 11(3): 373-380.

Hamad, A., N. A. Handayani, dan E. Puspawiningtyas. (2014). Pengaruh umur starter Acetobacter xylinum terhadap produksi nata de coco. Techno 15(1): 37-49.

Kristianingrum, S. (2004). Kandungan Gizi Nata De Coco. Pendidikan Kimia FMIPA Universitas Negeri Yogyakarta.

Apriyanto, M., Sutardi dan Santosa, U., (2007) Recovery Protein Blodo Vco, Menggunakan Sistem Fisis Dan Mekanis, Tesis, Fakultas Teknologi Pertanian UGM

Maharani, F. H. dan M. Kusumaningrum. (2016). Pemberdayaan ibu rumah 
tangga melalui pelatihan

pembuatan nata de leri di

Kelurahan Banyumanik

Semarang. Abdimas Unwahas

1(1): 17-22.

Oedjijono.. (1983). Pemanfaatan limbah air kelapa untuk pembuatan nata de coco. Diakses pada http://bio.unsoed.ac.id/sites/defau lt/files/Pemanfaatan\%20Limbah $\% 20$ Air\%20Kelapa\%20untuk\%2 OPembuatan $\% 20$ Nata\%20de $\% 20$

Coco-_0.pdf 